\title{
ДОХОДНОСТЬ ПОРТФЕЛЬНЫХ КОМПАНИЙ ФОНДОВ ПРЯМЫХ ИНВЕСТИЦИЙ: НА ПРИМЕРЕ ПУБЛИЧНЫХ КОМПАНИЙ ЦЕНТРАЛЬНОЙ ЕВРОПЫ
}

\begin{abstract}
A.В. Прохоренко ${ }^{1}$
Статья посвящена анализу доходности портфельных компаний фондов прямых инвестиций, осуществивших первичное предложение акций, в Центральной Европе с 2004 по 2014 г. Способность фондов прямых инвестиций генерировать прибыль, превышающую рыночную доходность, остаётся дискуссионным вопросом в академической литературе в связи снеполной информацией о сделках фондов, которая находится в распоряжении исследователей. Анализ доходности портфельных компаний фондов прямых инвестиций, осуществивших публичное предложение акций, позволит в большей степени понять, насколько фонды способны генерировать прибыль, превышающую рыночную доходность. В статье анализируются агрегированные данные первичного публичного предложения акций 31 компании на Варшавской фондовой бирже с 2004 по 2014 г. с общим объемом более одного миллиарда долларов США. Параметрический и непараметрические тесты использованы для анализа статистической значимости отличия первоначальной и долгосрочной доходности акций портфельных компаний от доходности рынка. Тест Манна-Уитни использован для анализа разницы между средними значениями доходности акций компаний после разделения выборки на подгруппы на основе критериев: стадия развития рынка, отрасль, неопределенность ехante, превышение лимита подписки, уменьшение доли владения. Множественная регрессия использована для определения факторов, влияющих на первоначальную доходность акций компаний, превышающую рыночную доходность. Результаты анализа соответствуют выводам схожих исследований: первоначальная доходность акций компаний превышает рыночную доходность; долгосрочная доходность акций компаний статистически не отличается от доходности рынка. Основными факторами, определяющими первоначальную доходность, являются: неопределенность ex-ante, превышение лимита подписки и отрасль, в которой работает компания.
\end{abstract}

Ключевые слова: Фонды прямых инвестиций, первичное публичное предложение акций, доходность акций, Центральная Европа

JEL: G12, G24

\section{Введение}

Доходность фондов прямых инвестиций продолжает привлекать пристальное внимание исследователей вне зависимости от региона деятельности фондов. Главный вопрос заключается в том, могут ли фонды прямых инвестиций в среднем генерировать прибыль, превышающую рыночную доходность, или нет. В основном доходность фондов прямых инвестиций зависит от доходности компаний, которые входят в инвестиционный портфель фондов. Основным источником данных для анализа доходности портфельных компаний и фондов прямых инвестиций являются коммерческие базы данных. В связи с закрытым характером коммерческих баз данных анализ публичных компаний позволяет пролить свет на доходность отдельных активов, которые входят в инвестиционный портфель фондов прямых инвестиций.

Публичное предложение акций является для фондов одним из вариантов выхода из инвестиций в частные компании наряду с продажей стратегическому инвестору, другому фонду, менеджменту компании или реструктуризацией. Информация о сделках зачастую не раскрывается, т.к. фонды прямых инвестиций инвестируют в основном в частные компании. Публичные компании, наоборот, обязаны раскрывать информацию о своих финансовых показателях, акционерах и капитале, а цена акций отражается на фондовой бирже в режиме

1. МГУ им.Ломоносова М.В., Экономический факультет, аспирант; Ситибанк Европа, Специалист по обработке ценных бумаг 
реального времени. Таким образом, анализ публичных компаний, чьи акции были размещены на фондовой бирже при участии фондов, позволит узнать больше не только о самих компаниях, но и о фондах на примере отдельных портфельных компаний.

Целью данной статьи является анализ краткосрочной и долгосрочной доходности компаний, чьи акции были размещены на фондовой бирже при участии фондов прямых инвестиций. В связи с тем что размещение акций компаний, которые находятся в инвестиционном портфеле фондов, является одним из вариантов выхода для фондов из инвестиций, может возникнуть ситуация, когда фонды заинтересованы в извлечении максимальной прибыли от публичного предложения в краткосрочной перспективе.

Ряд исследователей отмечают, что фонды прямых инвестиций положительно влияют на доход, операционную деятельность и продуктивность своих портфельных компаний [Jensen, 1989; Lichtenberg, Siegel, 1989; Guo, Hotchkiss, Song, 2008; Wilson, Wright, 2013]. Если данная точка зрения соответствует действительности, то можно предположить, что портфельные компании после публичного предложения в долгосрочной перспективе будут показывать положительную динамику доходности при прочих равных условиях.

В качестве региона исследования была выбрана Центральная Европа. Во-первых, данный регион географически близок к России и исторически прошел схожий экономический путь развития. Во-вторых, вопросам частного инвестирования в Центральной Европе пока еще не уделено достаточно внимания в научной литературе. В-третьих, фактор доступности данных также сыграл роль при выборе региона исследования. Так как больше всего публичных предложений акций при участии фондов прямых инвестиций было осуществлено в Польше, то практическая часть исследования основана на данных первичного предложения акций компаний на Варшавской фондовой бирже, хотя выводы исследования можно отнести ко всему региону.

В научной литературе представлена довольно широкая доказательная база того, что первоначальная доходность первичного предложения акций выше рыночной доходности [Ibbotson, 1975], а долгосрочная доходность акций ниже рыночной доходности [Ritter, 1991]. Обе статьи, указанные выше, анализировали первичное предложение акций компаний на фондовых рынках США. В последующих исследованиях методология оценки доходности акций относительно рынка совершенствовалась и тестировалась на данных других рынков [Al-Hassan, Delgado and Omran, 2007;Agarwal, Liu and Rhee, 2008\$ How, Izan and Monroe, 2009; Sieradzki, 2013].

К. Рокк [Rock, 1986] создал модель равновесия рынка первичного предложения акций. Основные выводы данной модели заключаются в том, что асимметрия информации влияет на цену акций во время первичного публичного предложения. Информированные инвесторы купят только акции компаний, которые принесут в будущем доход, поэтому спрос на акции данных компаний превышает предложение. Инвесторам, не обладающим информацией, остаются акции компаний, которые, как ожидается, не принесут существенного дохода в будущем. Для того чтобы привлечь инвесторов, не обладающих информацией, данные компании понижают цену своих акций ниже рыночной стоимости.

Ф. Аллен, Г. Фалхабер [Allen and Faulhaber, 1989] и И. Уэлш [Welch, 1989] развили теорию передачи сигналов, по которой оценка компании ниже рыночной стоимости служит сигналом, посылаемым инвесторам, для дальнейшей покупки акций во время вторичного предложения. Компания занижает стоимость своих акций и размер первичного публичного предложения, давая возможность рынку найти справедливую стоимость акций. Рост цены акции после первичного предложения стимулирует будущий спрос на акции данной компании, что позволяет ей осуществить вторичное предложение акций по завышенным ценам, которые окупят потенциальную упущенную выгоду во время первичного предложения.

Ряд работ был посвящен применению методологии оценки доходности первичного предложения акций на разных фондовых рынках. А. Ал-Хассан, Ф. Дельгадо и М. Омран [Al-Hassan, Delgado and Omran, 2007] дополнили методологию исследования, расширив 
показатели доходности, и применили ее для анализа первичных предложений акций на фондовых рынках стран Совета содружества арабских государств Персидского залива.

Р. Щерадзки [Sieradzki, 2013] применил схожую методологию для анализа доходности первичных предложений акций на фондовой бирже Варшавы. Основные выводы совпадают с большинством исследований: первоначальная доходность акций выше рыночной доходности, а доходность в долгосрочной перспективе ниже рыночной доходности. В качестве основных факторов, определяющих первоначальную доходность, в статье выделяются: неопределенность ех-ante, выраженная через волатильность Паркинсона; спрос на акции во время первичного предложения; отрасль, в которой работает компания.

Следующий параграф данной статьи посвящен обзору фондовых рынков стран Центральной Европы и Балтики. Анализируется динамика капитализации фондовых рынков, отношение объемов капитализации к объему ВВП стран, динамика рыночного индекса и индекса, составленного на основе цен акций исследуемых компаний. Методология исследования представлена в третьем параграфе. Выборка, на основе которой проведено исследование, анализируется в четвертом параграфе, в котором представлена также и описательная статистика. Пятый параграф посвящен результатам исследования.

\section{Обзор развития фондового рынка в странах Центральной Европы и Балтии}

Большинство фондовых рынков Центральной и Восточной Европы получили повторное рождение в начале 1990-х годов. По данным Всемирного Банка, до 2004 г. капитализация фондового рынка России и совокупная капитализация фондового рынка стран Центральной Европы и Балтии были примерно на одном уровне. С 2004 г. фондовый рынок России переживал бурный подъем и к 2007 году превысил 1.4 трлн долл. США, тогда как совокупная капитализация стран Центральной Европы и Балтии достигла только 0,5 трлн долл. США. В 2008 г. фондовый рынок России и рынкиЦентральнойЕвропы ощутилипадение:капитализация российского фондового рынка снизилась до 400 млрд долл., а стран Центральной Европы и Балтии - до 237 млрд долл. К 2010 г. рынок России восстановился до уровня капитализации в 1 трлн долл., а Центральной Европы - до 350 млрд долл. График 1 подробнее представляет данные о динамике капитализации фондового рынка России и совокупной капитализации стран Центральной Европы и Балтии.

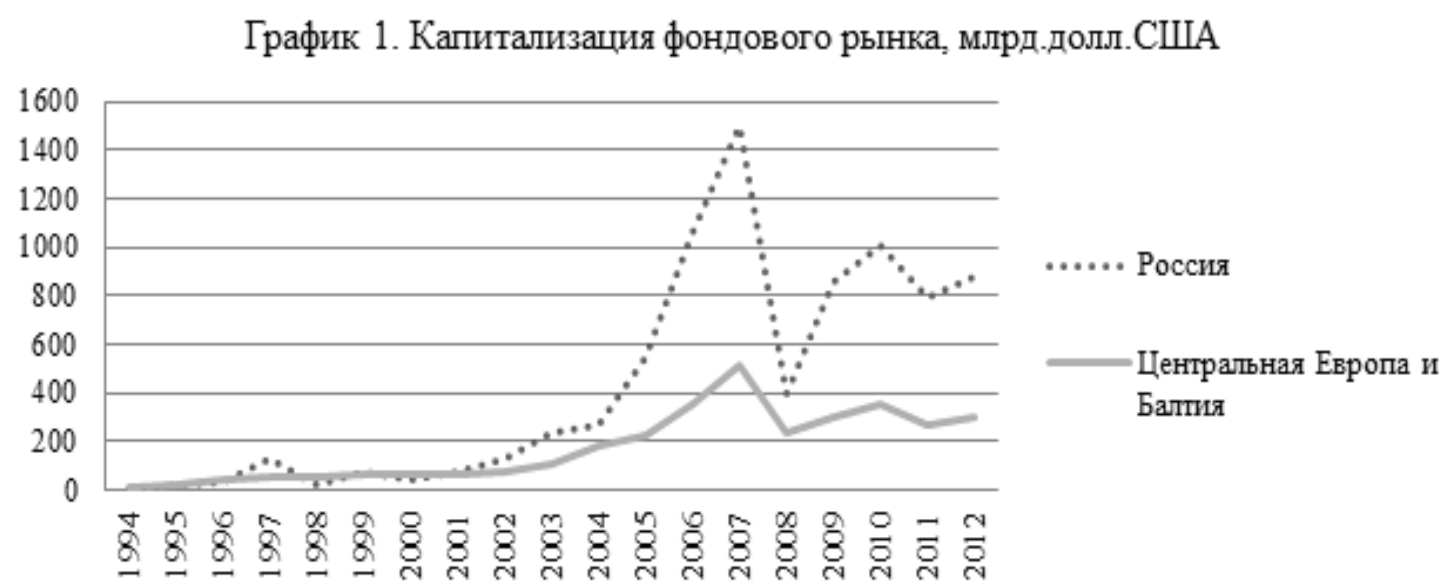

График 1. Капитализация фондового рынка, млрд долл. США

Показатель отношения капитализации фондового рынка к ВВП позволяет сопоставить размер фондового рынка и размер экономики страны. На графике 2 представлены совокупный показатель для стран Центральной Европы и Балтии, показатель для Польши и России. С 1991 по 2008 г. отношение капитализации фондового рынка к ВВП для всех стран Центральной Европы и Балтии и для Польши были сопоставимы, расхождения начались с 2009 г., когда данный показатель для Польши начал опережать совокупный показатель стран Центральной Европы и Балтии. 
График 2. Капитализация фондового рынка, \% от ВВП

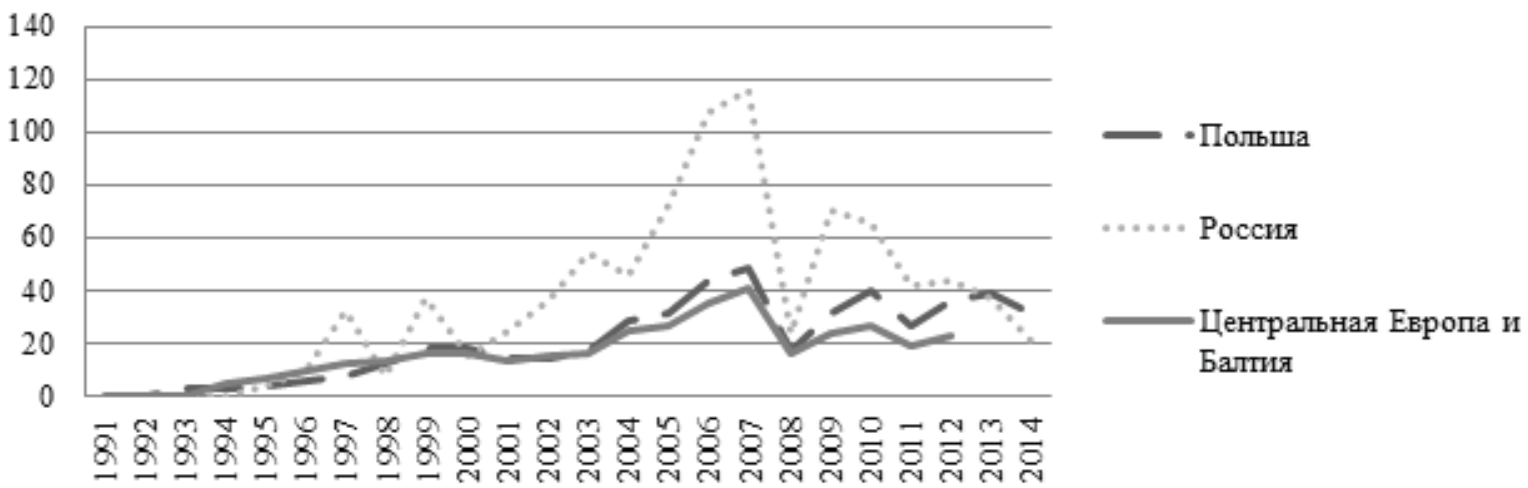

График 2. Капитализация фондового рынка, \% от ВВП

Источник: 1991-2012 - Всемирный Банк; 2013-2014 - Всемирная федерачия фондовых бирж, вычисления автора..

Отношение капитализации фондового рынка к ВВП России начало опережать данное отношение для стран Центральной Европы и Балтии после 2000 г., когда фондовый рынок России вырос с 20\% относительно ВВП в 2000 г. до 115\% в 2007 г.. В 2008 г. капитализация фондового рынка России упала до 20\%, но с 2009 г. фондовый рынок начал расти относительно ВВП. В 2013 г. капитализация польского фондового рынка относительно ВВП впервые стала больше капитализации фондового рынка России. В 2014 г. фондовый рынок России еще больше потерял в цене. Капитализация фондового рынка Польши относительно ВВП также снизилась в 2014 г., но не так значительно, как это было с российским фондовым рынком.

Около 98\% совокупной капитализации стран Центральной Европы и Балтии приходится на три страны: Польшу, Венгрию и Чехию. Доля Польши при этом выросла с 24\% относительно общей капитализации в 1994 г. до 60\% в 2012 г. Доля Чехии при этом уменьшилась с 46\% в 1994 г. до 12\% в 2012 г. Доля Венгрии снизилась с 12\% в 1994 г. до 7\% в 2012 г. Как можно увидеть на графике 3 , доли Венгрии и Чехии постепенно снижались в совокупной капитализации фондовых рынков стран Центральной Европы и Балтии, а доля Польши постоянно росла.

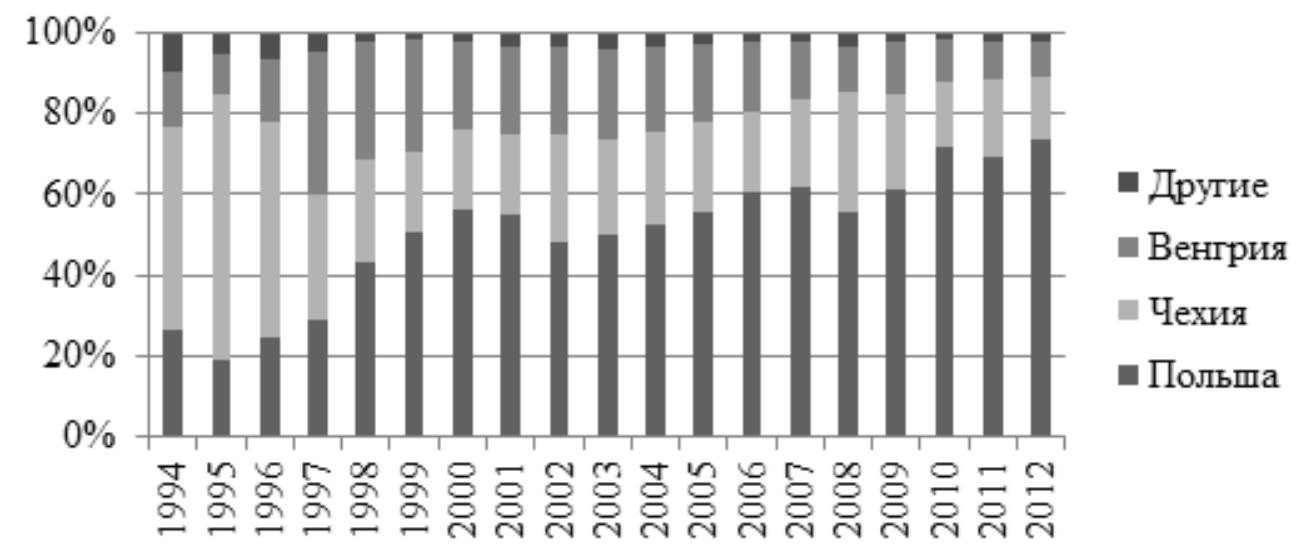

График 3. Капитализация фондовых рынков стран Центральной Европы и Балтии Источник: Всемирный Банк, вычисления автора

Варшавская фондовая биржа открылась в 1991 г. в 2015 г. девять компаний осуществили публичное предложение акций, чья капитализация составляла 152 млн долл. За 24 года своего существования фондовая биржа Варшавы выросла до 474 компаний, а капитализация превысила 163 млрд долл. в 2015 г. Как видно на графике 4, развитие фондового рынка Польши можно разделить на два этапа: к первому этапу можно отнести 1991-2004 г.; ко второму этапу - период с 2004 г. и до настоящего времени. Как видно из графика, во время первого этапа количество компаний выросло с 9 до 200. Второй этап начался с вступлением страны в Европейский Союз, и количество компаний, осуществивших первичное предложение акций на фондовой бирже Варшавы, неуклонно растет, превысив 450 в 2014 г. Капитализация также растет, исходя из графика, превысив 180 млрд долл. в 2007, 2013 и 2014 гг. 


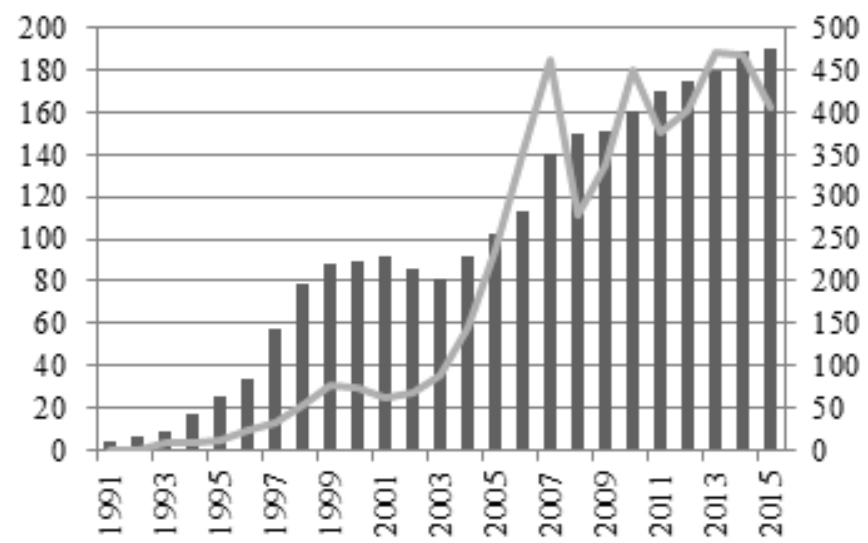

Количество компаний

- Капитапизация,

млрд.долл.

График 4. Фондовый рынок Польши (количество компаний - правая шкала, капитализация -- левая)

Источник: данные по фондовому рынку - Варшавская фондовая биржа;

1991-2014 - годовые значения; 2015 год - данные с января по июль..

Объем фондового рынка привлекает не только частные компании к публичному размещению акций, но и фонды прямых инвестиций для размещения акций своих портфельных компаний. С 1993 по 2014 г. 14 фондов прямых инвестиций разместили акции 50 компаний, динамику данного процесса можно увидеть на графике 5. Видно две большие волны первичных предложений: с 1993 по 1998 г. с пиком в 1997 г. и с 1999 по 2008 г. с пиком в 2006 г. С 2008 г., судя по графику, началась третья волна.

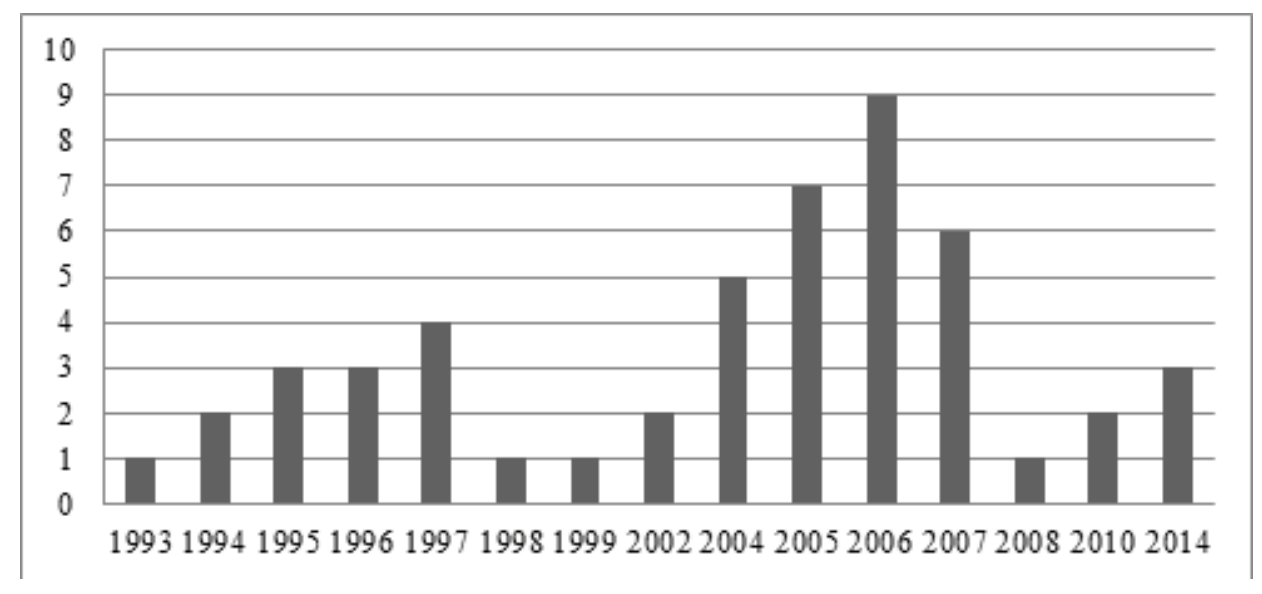

График 5. Публичное предложение акиий компаний, принадлежащиих фондам прямых инвестищий

Источник: 1993-2010 - [Клоновски, 2011]; 2011 -2014-пресс-релизы компаний.

График 6 позволяет сравнить динамику индекса Варшавского фондового рынка (WIG) и индекс, составленный на основе динамики цен акций компаний, которые были выведены на фондовый рынок при участии фондов прямых инвестиций (ФПИ). Как можно увидеть на графике при осуществлении пассивной инвестиционной стратегии доходность акций компаний, которые входят в индекс WIG, существенно превышает доходность акций компаний, которые были выведены на фондовый рынок при участии фондов.

Одна денежная единица, инвестированная в рыночный индекс 22 июня 1993 г., принесла бы инвестору 20,42 денежных единиц 6 июля 2007 года. При этом инвестиции в акции компаний, которые были выведены на фондовый рынок при участии фондов, принесли бы только 2.94 денежных единиц. Если максимальное значение индекса WIG наблюдалось в 2007 г., то, как видно на графике, максимальная совокупная доходность акций компаний, которые были выведены на фондовый рынок при участии фондов, была 27 января 1994 г., когда индекс достиг 5,66. 


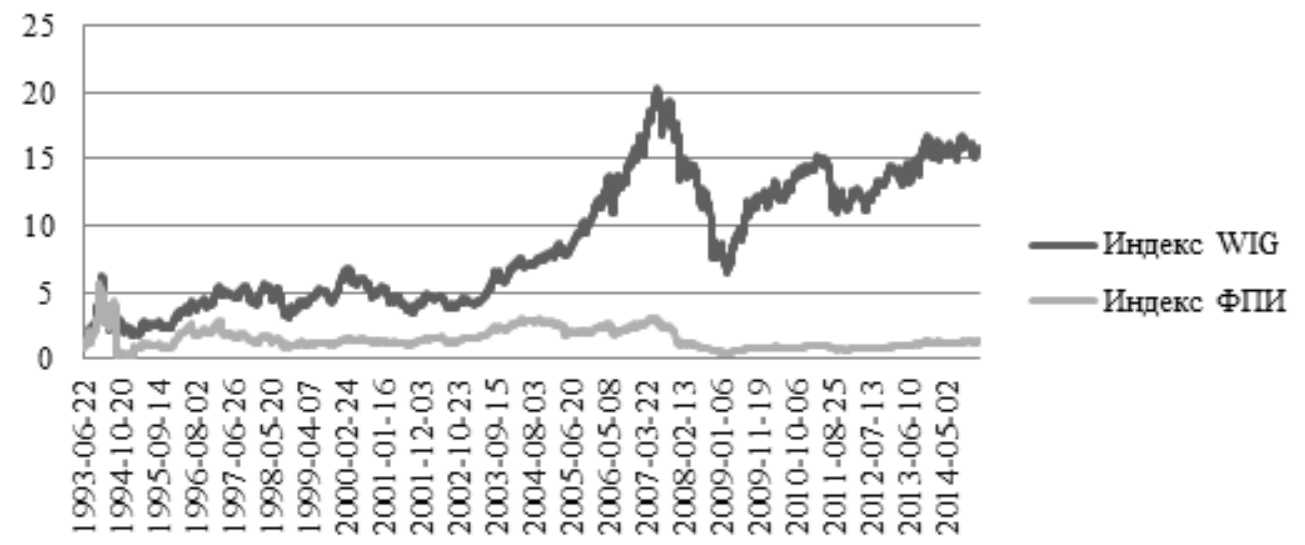

График 6. Индекс WIG и индекс ФПИ при инвестищчии

одной денежной единицы 22 июня 1993 г.

Источник: Архив Варшавской биржи. Составление и подсчет автора..

Существенное отличие в показателях доходности индексов может привести к неверным выводам, т.к. фонды прямых инвестиций исходят из активной инвестиционной стратегии и для них вывод компаний на публичный рынок является возможностью реализации прибавочной стоимости, созданной за то время, когда та или иная компания находилась в инвестиционном портфеле фонда. Таким образом, фонды больше заинтересованы в диапазоне цен акции, по которой будет формироваться подписка, нежели в долгосрочных показателях доходности своих портфельных компаний.

Следующие разделы статьи посвящены статистическому анализу доходности акций компаний, которые осуществили публичное предложение при участии фондов прямых инвестиций. Интересует ответ на три вопроса: является ли цена акций компаний во время периода подписки недооцененной; какие факторы влияют на первоначальную доходность акций компаний; могут ли акции компании в долгосрочной перспективе показывать доходность, превышающую рыночную доходность.

\section{Методология}

Первоначальная доходность и доходность после осуществления публичного предложения акций подсчитаны с использованием динамики цен акций компаний и рыночного индекса для рынка Польши (WIG). Параметрический тест и непараметрический тест Уилкоксона использованы для оценки доходности, превышающую рыночную доходность, в краткосрочной и долгосрочной перспективе. Помимо этого, U-тест по методу Манна и Уитни использован для сравнения средних значений доходности между выборками, сформированными по времени первичного предложения акций, отрасли, неопределенности ex-ante, превышения лимита подписки, изменению доли владения фондом прямых инвестиций компании. Множественная регрессия построена для анализа факторов, влияющих на доходность первичного предложения акций.

\section{Первоначальная и долгосрочная доходность акиий}

Первоначальная доходность акций, превышающая рыночную доходность

Первоначальная доходность акций во время первичного размещения рассчитана по нижеприведенной формуле:

$r_{i}=\frac{P_{i, t}-P_{i, 0}}{P_{i, 0}}$,

где:

$r_{i}$ - первоначальная доходность акции $i$ от периода подписки на акции до закрытия первого торгового дня.

$P_{i, t}$ - цена закрытия акции $i$ в первый торговый день, 
$P_{i, 0}-$ цена предложения во время подписки на акции.

К сожалению, вышеприведенная формула не может достоверно показывать первоначальную доходность акций, в связи с тем что существует ряд сопутствующих инвестициям издержек, которые несут инвесторы. Во-первых, инвестор сталкивается с транзакционными издержками. Во-вторых, инвестор может понести издержки в связи с тем, что его спрос на акции не реализован в полном объеме [Al-Hassan, Delgado and Omran, 2007].

Расширенная формула для подсчtта первоначальной доходности представлена ниже:

$r_{i}=\frac{P_{i, t}-P_{i, 0}}{P_{i, 0}}-\left[\frac{A R F_{0, t}(S D-T D)}{365} *(1-\varphi)+\frac{T C_{i}}{P_{i, 0}}\right]$,

где:

$A R F_{0, t}$ - средняя безрисковая доходность от даты подписки до начала торговли;

(SD - TD) - количество дней между последним днем подписки на акции (subscription day) и первым торговым днём (trading day);

$\varphi$ - процент предложенных акций относительно общего количества акций компании;

ТC - транзакционные издержки для каждой акции.

Доходность, превышающая рыночную доходность, подсчитана как разница между первоначальным доходом и доходностью рынка от последнего дня подписки на акции до закрытия первого торгового дня:

$a r_{i}=r_{i}-r_{c r p}$,

где:

$a r_{i}$ - чистый первоначальный доход, превышающий рыночную доходность, для акции $i$, $r_{c r p}$ - рыночная доходность от последнего дня подписки на акции до закрытия первого торгового дня.

$r_{\text {crp }}$ подсчитана по формуле:

$r_{c r p}=\frac{I_{i, t}-I_{i, 0}}{I_{i, 0}}$

где:

$I_{i, t}$ - значение рыночного индекса на момент закрытия первого торгового дня для акции $i$,

$I_{i, 0}-$ значение рыночного индекса на день закрытия подписки на акцию $i$.

\section{Долгосрочная доходность акичий, превышающяая рыночную доходность}

Существует несколько методологий подсчета долгосрочной доходности акций относительно рынка. Для целей данной статьи выбрана методология подсчета доходности акций при использовании пассивной инвестиционной стратегии. По данной методологии, сравниваются между собой ежедневные показатели доходности акции и рыночного индекса, затем считается капитализированный доход, превышающий рынок, и берется среднее значение относительно всех акций в выборке.

Нижеприведенная формула описывает данную процедуру математическим языком:

$a R_{i, T}=R_{i, T}-R_{c r p, T}$,

или:

$a R_{i, T}=\left[\prod_{t=1}^{\min (T, \text { delisting })}\left(1+r_{i, t}\right)-1\right]-\left[\prod_{t=1}^{\min (T, \text { delisting })}\left(1+r_{c r p, t}\right)-1\right]$,

где $a R_{i, T}$ - доход акции $i$, превышающий рыночную доходность, при пассивной инвестиционной стратегии в течение периода T, который равняется 252 дням. 
Нулевая гипотеза состоит в том, что средняя первоначальная доходность, превышающая рынок, и средняя доходность после первичного предложения при реализации пассивной инвестиционной стратегии равны нулю для выборки, состоящей из $n$ количества первичных предложений акций. Альтернативная гипотеза состоит соответственно в том, что доходность не равна нулю. Тесты осуществляются по нижеприведенным формулам:

$$
t_{a r}=\frac{a v \cdot a r}{\left(\sigma_{a r} / \sqrt{n}\right)},
$$

и

$$
t_{a R}=\frac{a v \cdot a R_{T}}{\left(\sigma_{a R_{T}} / \sqrt{n}\right)},
$$

где:

av.ar и $a v \cdot a R_{T}$ - средние значения первоначальной доходности и долгосрочной доходности, превышающих рыночную доходность;

$\sigma_{a r}$ и $\sigma_{a R t}-$ стандартные отклонения средних значений первоначальной доходности и долгосрочной доходности, превышающих рыночную доходность.

На основе нулевой гипотезы данные статистики должны следовать t-дистрибуции Стьюдента, если выборка нормально распределена. В связи с тем, что выборка не попадает под определение нормального распределения, помимо t-критерия использован критерий Уилкоксона. Для сравнения средних значений доходности по разным параметрам использован $\mathrm{U}$-тест по методу Манна и Уитни.

\section{Факторы, влияющие на первоначальную доходность}

Для анализа факторов, которые влияют на первоначальную доходность, мы прибегаем к множественной регрессии. Список независимых переменных приведен ниже.

Одно из объяснений того, что акции во время первичного предложения оцениваются по цене ниже рыночной стоимости, является неопределенность, связанная с будущими показателями компании. Неуверенность инвесторов может повлиять на их намерение покупать или не покупать акции той или иной компании. Чем больше неопределенность по поводу будущих финансовых показателей компании, тем ниже должна быть цена акций для привлечения инвесторов. В литературе существуют несколько способов оценки неопределенности, связанной с будущими результатами компании. Кнопф и Тилл [Knopf and Teall, 1999] доказали, что волатильность Паркинсона дает более точную оценку неопределенности ехante. Волатильность Паркинсона (Parkinson's Extreme Value) считается по формуле:

$$
P E V=\ln \frac{P_{i, 0} \max }{P_{i, o} \min },
$$

где:

$P_{i, 0} \max$ - максимальная цена первого торгового дня акций компании $i$, $P_{i, 0} \min$ - минимальная цена первого торгового дня акций компании $i$.

Превышение лимита подписки. Оценка стоимости акций ниже рыночной стоимости может быть связана с асимметрией информации и с теорией, развитой К. Рокком [Rock, 1986]. Оценка ниже рыночной может быть вызвана тем, что информированные инвесторы купили акции компаний, которые, как ожидается, будут расти. Компании, у которых предложение акций превышает спрос, вынуждены предлагать цену ниже рыночной для привлечения инвесторов, не обладающих информацией. 
Пропорция акций, которая была предложена для покупки. Заниженная цена акций и небольшая доля, которую предлагают компании во время первичного предложения акций, может быть связана с теорией передачи сигналов. Исходя из данной теории, компании осуществляют выход на рынок в два шага. Во время первого шага компания предлагает сравнительно небольшую часть акций по цене с дисконтом. Данный шаг должен настроить положительно инвесторов, которые сразу получат прибыль от инвестиций в акции. Во время вторичного предложения акций компании предлагают акции по завышенным ценам, что должно принести покрытие упущенной выгоды во время первичного предложения. Таким образом, ожидается отрицательная связь между пропорцией предложенных акций и первоначальной доходностью. Пропорция акций, предложенная во время первичного предложения, оценивается как отношение предложенных акций к общему количеству акций компании [Allen and Faulhaber, 1989; Welch, 1989].

Волатильность рынка. Степень отклонения цены акции во время первоначального предложения от рыночной стоимости может также зависеть от волатильности рынка. Исследователи нашли позитивную связь между волатильностью рынка и первоначальной доходностью. Это. скорее всего. связано с тем, что во время высокой волатильности рынка компании заинтересованы в снижении вероятности неудачного размещения и занижают цену акций, тем самым привлекая инвесторов. Рыночная волатильность оценивается как стандартное отклонение дневных данных рыночного индекса за два месяца до закрытия периода подписки [Menyah, Paudyal and Inyangete, 1995].

Настроениеучастников рынка.Рядисследователей нашлиположительнуюсвязь между стадией развития рынка и первоначальной доходностью. Существуют некоторые доказательства, что во время подъема рынка количество удачных первичных предложений выше по сравнению с рецессией [Derrien and Womack, 2003].

Тип отрасли. Некоторые авторы также отмечают, что первоначальная доходность акций компаний зависит от типа отрасли [Aggraval and Rivoli, 1990].

Таким образом, уравнение множественной регрессии выглядит как::

$a r_{i}=\alpha+\beta_{1} E_{X A N T E}+\beta_{2} O V R S_{i}+\beta_{3} P_{S O}+\beta_{4} M V_{i}+\beta_{5} T_{I} M_{i}+\beta_{6} I N D_{i}+\varepsilon_{I}$,

где:

$E X A N T E_{i}$ - неопределенность ex-ante,выраженная через волатильность Паркинсона;

$O V R S_{i}$ - превышение лимита подписки, выраженное через отношение спроса на акции к предложению;

$P S O_{i}-$ пропорция акций, предложенных во время первичного предложения относительно общего количества акций;

$M V_{i}$ - рыночная волатильность, выраженная через стандартное отклонение дневных данных изменения рыночного индекса два месяца перед окончанием подписки на акции;

$T I M_{i}$ - фиктивная переменная, где единица означает «бычий» рынок, а ноль - «медвежий»; $I N D_{i}$ - фиктивная переменная, где единица означает отрасль финансов или информационных технологий, а ноль - все остальные.

\section{Набор данных и конструирование выборки}

В выборку включены данные об изменении цен акций польских компаний, которые осуществили публичное предложение при участии фондов прямых инвестиций с 2004 по 2014 г. Всего в выборку включены данные по 31 компании с общим объемом предложения акций свыше 1 млрд долл. В таблице 1 представлен временной ряд данных по количеству и объему предложений. 
Первичное публичное предложение акций компаний, принадлежащих фондам прямых инвестиций

\begin{tabular}{|c|c|c|}
\hline & Количество & Объем, млн. долл. \\
\hline 2004 & 5 & 135 \\
\hline 2005 & 7 & 384 \\
\hline 2006 & 8 & 115 \\
\hline 2007 & 5 & 222 \\
\hline 2008 & 1 & 8 \\
\hline 2010 & 2 & 35 \\
\hline 2014 & 3 & 181 \\
\hline Всего & 31 & 1080 \\
\hline
\end{tabular}

Всего 13 фондов прямых инвестиций осуществили первичное предложение акций 31 компании. Пять фондов в выборке осуществили предложение по одной компании каждый; пять фондов - по две компании каждый. Только три фонда из выборки осуществили предложение акций более двух компаний каждый: Enterprise Investors - девять компаний, MCI - четыре компании, Capital Partners - три компании.

Анализ динамики первичных предложений показывает, что пиком по количеству компаний, чьи акции были предложены на фондовом рынке при помощи фондов прямых инвестиций, является 2006 г., когда девять компаний осуществили публичное предложение. При этом пиком по объему первичного предложения является 2007 г., когда семь компаний продали акции на 384 млн долл.

Больше всего компаний, осуществивших первичное предложение акций при помощи фондов, было из отрасли производства - 10 компаний. Второе по популярности место занимает отрасль информационных технологий с шестью компаниями. Помимо названных отраслей, компании были также из отраслей, связанных с торговлей, энергетикой, финансами, питанием, СМИ и др.

Источниками данных для исследования являются архив Варшавской фондовой биржи, прессрелизы компаний, статьи в профессиональной прессе, статистика Национального банка Польши. Архив Варшавской фондовой биржи содержит информацию о дневных изменениях цен компаний с первого дня размещения акций до последнего дня торговли. Пресс-релизы компаний посвящались основным стадиям выхода акций компаний на рынок: формирование заявочной книги, спрос и предложение акций. Из статей в профессиональной прессе удалось получить информацию об изменении акционеров компаний. Национальный банк Польши хранит информацию о месячных показателях кредитных ставок.

В среднем первоначальная доходность первичного предложения акций равнялась 11\%, тогда как средняя рыночная доходность равнялась только 2\%. Максимальное значение первоначальной доходности при этом равнялось 85\%, тогда как максимальная доходность рынка - только 17\%. Минимальная первоначальная доходность при этом составила - $14 \%$ при минимальном доходе рынка 10\%. Показатель риска, представленный в таблице в виде стандартного отклонения, указывает на то, что риск первоначальной доходности первичного размещения акций выбранных компаний был на 14\% выше рыночного риска. Это укладывается в рамки теории эффективного рынка и линейной зависимости между доходом и риском.

Коэффициент асимметрии и эксцесса позволяет понять форму распределения данных в выборке и оценить, попадают ли они под определение нормального распределения. Как можно увидеть, коэффициент асимметрии рыночной доходности превышает нулевое значение в меньшей степени, чем показатель первоначального дохода 


\begin{tabular}{cccc} 
& \multicolumn{3}{c}{ Описательная статистика } \\
\hline Первоначальный доход & & Первоначальный доход выше рынка \\
Среднее & $11 \%$ & Среднее & $8 \%$ \\
Медиана & $4 \%$ & Медиана & $2 \%$ \\
Минимум & $-14 \%$ & Минимум & $-11 \%$ \\
Максимум & $85 \%$ & Максимум & $77 \%$ \\
Ст. откл. & 0,20 & Ст. откл. & 0,19 \\
Эксцесс & 5,40 & Эксцесс & 5,15 \\
Асимметрия & 2,12 & Асимметрия & 2,11 \\
Количество & 31 & Количество & 31 \\
& & & \\
\cline { 2 - 4 } & & Долгосрочный доход & \\
Рыночный доход & $2 \%$ & Среднее & $-3 \%$ \\
Меднее & $0 \%$ & Медиана & $-2 \%$ \\
Минимум & $-10 \%$ & Минимум & $-64 \%$ \\
Максимум & $17 \%$ & Максимум & $63 \%$ \\
Ст. откл. & 0,06 & Ст. откл. & 0,37 \\
Эксцесс & 0,52 & Эксцесс & $-1,07$ \\
Асимметрия & 0,47 & Асимметрия & 0,05 \\
Количество & 31 & Количество & 30 \\
\hline
\end{tabular}

Показатель асимметрии долгосрочной доходности ближе к нормальному распределению, чем первоначальная доходность. Коэффициент эксцесса выше коэффициента эксцесса нормального распределения при анализе первоначального дохода и ниже данного показателя при анализе рыночной доходности и долгосрочной доходности. Таким образом, необходимо с осторожностью относиться к выводам параметрических тестов в связи с тем, что выборка не соответствует характеристикам нормального распределения.

\section{Эмпирические результаты анализа}

\section{Первоначальная доходность, превышающая рынок}

Средняя первоначальная доходность, превышающая доходность рынка, составила 7,85\%. Данный доход получен путем подписки на акции инвесторами во время заявочного периода и продажи акции по цене закрытия первого торгового дня. Результат t-теста показывает значимость отличия средней первоначально доходности, превышающей рыночную доходность, от нуля при 5\%-ном уровне значимости. В связи с тем что данные в выборке не распределены нормально, использован непараметрический тест, который подтвердил выводы t-теста. В таблице 4 представлены основные результаты статистического анализа.

В исследовании Р. Щерадзкого [Sieradzki, 2013], посвященном доходности первичного предложения акций на Варшавской фондовой бирже с 2003 по 2011 г., первоначальная доходность первичного предложения была в среднем на 14,2\% выше рыночной доходности. Можно предположить, что фонды прямых инвестиций ближе к оценке справедливой стоимости портфельных компаний во время первичного предложения акций относительно всего рынка первичного предложения акций в Польше, хотя оценка акций портфельных компаний фондов прямых инвестиций также была ниже цены, сформированной рынком после первичного предложения.

Большинство акций компаний было предложено во время роста рынка. Только акции пяти компаний были предложены во время спада экономической активности. Разница между средней первоначальной доходностью акций, которые были предложены во время экономического роста, статистически незначима по сравнению со средней первоначальной доходностью акций, которые были предложены во время экономического спада. 
Отрасль, в которой работает компания, также не имеет существенного значения для первоначальной доходности, как показало исследование. Хотя средняя первоначальная доходность в отраслях финансов и информационных технологий составила около $14,55 \%$, а средняя первоначальная доходность акций из других отраслей - только 5,11\%, непараметрический тест Манна-Уитни показывает то, что различие между значениями статистически незначимо.

Неопределенность ех-ante также статистически не играет роли в определении первоначальной доходности акций. Сравнение проводилось между двумя группами компаний: у первой группы волатильность Паркинсона равнялась или превышала $10 \%$, у второй группы была меньше 10\%. Характерно, что у первой группы средняя доходность была $13,41 \%$, а у второй - только 3,28\%. Тем не менее U-критерий Манна-Уитни превышает табличное значение, из чего следует, что разница в доходности между данными двумя группами статистически незначима.

Есливремя, отрасль и неопределенностьнеявляются значимымипеременнымив разграничении успешных и неудачных первичных предложений акций, то разница в спросе на акции является статистически значимой переменной. В 23 случаях спрос на акции превышал предложение и только в восьми случаях был меньше или равен предложению. Средняя первоначальная доходность акций, у которых спрос превышал предложение, равнялась 11,29\%, тогда как средняя доходность остальных акций была отрицательной - $-2,03 \%$. Данное отличие является статистически значимым при 5\%-ном уровне значимости с z-критерием 1,92.

Таблица 3

Первоначальная доходность, превышающая рынок

\begin{tabular}{|c|c|c|c|c|c|}
\hline \multicolumn{4}{|c|}{ Панельный анализ 1: Общая выборка (31 компания) } & & \\
\hline Фирмы с доходом > 0 & $\begin{array}{c}\text { Фирмы с доходом } \\
\leq 0\end{array}$ & Среднее (медиана) & t-критерий & & \\
\hline (z-критерий) & 12 & $7.85 \%$ & 2.31 & & \\
\hline 19 & 12 & $7,85 \%$ & 2,31 & & \\
\hline & & & $(2,3 \%)$ & $(1,67)$ & \\
\hline $\begin{array}{c}\text { Панельный анализ 2: } \\
\text { Сравнение доходности в } \\
\text { зависимости от года IPO }\end{array}$ & & $\begin{array}{l}\text { Средняя доходность во время } \\
\text { медвежьего рынка (медиана) }\end{array}$ & z-критерий & & \\
\hline $\begin{array}{c}\text { Количество IPО во время } \\
\text { «бычьего» рынка («медве- } \\
\text { жьего») } \\
\end{array}$ & $\begin{array}{c}\text { Средняя доходность } \\
\text { во время «бычьего» } \\
\text { рынка (медиана) }\end{array}$ & $\begin{array}{c}\text { Средняя доходность во } \\
\text { время «медвежьего» рынка } \\
\text { (медиана) }\end{array}$ & z-критерий & & \\
\hline 26 & $8,05 \%$ & $6,81 \%$ & 0,24 & & \\
\hline \multicolumn{3}{|c|}{ (5) } & $(2,25 \%)$ & $(4,08 \%)$ & \\
\hline $\begin{array}{c}\text { Панельный анализ 3: } \\
\text { Сравнение доходности в } \\
\text { зависимости от отрасли }\end{array}$ & & $\begin{array}{c}\text { Средняя доходность в } \\
\text { отраслях отличных от } \\
\text { финансов и ИТ (медиана) }\end{array}$ & z-критерий & & \\
\hline $\begin{array}{c}\text { Количество IPО в от- } \\
\text { раслях финансы и ИТ } \\
\text { (остальные отрасли) }\end{array}$ & $\begin{array}{c}\text { Средняя доходность } \\
\text { в отраслях финансы } \\
\text { и ИТ (медиана) } \\
\end{array}$ & $\begin{array}{c}\text { Средняя доходность в отрас- } \\
\text { лях отличных от финансов и } \\
\text { ИТ (медиана) }\end{array}$ & z-критерий & & \\
\hline 9 & $14,55 \%$ & $5,11 \%$ & 0,54 & & \\
\hline \multicolumn{4}{|c|}{ (22) } & $(2,30 \%)$ & $(2,53 \%)$ \\
\hline $\begin{array}{c}\text { Панельный анализ 4: } \\
\text { Сравнение доходности } \\
\text { в зависимости от } \\
\text { неопределенности ex-ante }\end{array}$ & $\begin{array}{c}\text { Средняя } \\
\text { доходность IPO с } \\
\text { волатильностью } \\
\text { Паркинсона } \geq 0.1 \\
\text { (медиана) }\end{array}$ & $\begin{array}{c}\text { Средняя доходность IPO с } \\
\text { волатильностью Паркинсона } \\
<0.1 \text { (медиана) }\end{array}$ & $\begin{array}{c}\text { U - критерий } \\
\text { Манна-Уитни }\end{array}$ & & \\
\hline $\begin{array}{c}\text { Количество IPO с вола- } \\
\text { тильностью Паркинсона } \geq \\
0,1(<0,1) \\
\end{array}$ & $\begin{array}{c}\text { Средняя доходность } \\
\text { ІРО с волатильно- } \\
\text { стью Паркинсона } \geq \\
\text { 0,1 (медиана) } \\
\end{array}$ & $\begin{array}{c}\text { Средняя доходность IPO с } \\
\text { волатильностью Паркинсона } \\
<0,1 \text { (медиана) } \\
\end{array}$ & $\begin{array}{c}\text { U-критерий Ман- } \\
\text { на-Уитни } \\
\end{array}$ & & \\
\hline 14 & $13,41 \%$ & $3,28 \%$ & 142 & & \\
\hline \multicolumn{4}{|c|}{$(17)$} & $(3,47 \%)$ & $(2,09 \%)$ \\
\hline
\end{tabular}




\begin{tabular}{|c|c|c|c|c|c|}
\hline $\begin{array}{c}\text { Панельный анализ 5: } \\
\text { Сравнение доходности } \\
\text { в зависимости от } \\
\text { превышения лимита } \\
\text { подписки }\end{array}$ & $\begin{array}{c}\text { Средняя } \\
\text { доходность IPO со } \\
\text { спросом больше } \\
\text { предложения } \\
\text { (медиана) }\end{array}$ & $\begin{array}{c}\text { Средняя доходность IPO со } \\
\text { спросом меньше или равно } \\
\text { предложению (медиана) }\end{array}$ & Z-критерий & & \\
\hline $\begin{array}{c}\text { Спрос на акции во время } \\
\text { IPO больше предложения } \\
\text { (меньше или равно), коли- } \\
\text { чество компаний } \\
\end{array}$ & $\begin{array}{l}\text { Средняя доходность } \\
\text { IPО со спросом } \\
\text { больше предложе- } \\
\text { ния (медиана) } \\
\end{array}$ & $\begin{array}{c}\text { Средняя доходность IPO со } \\
\text { спросом меньше или равно } \\
\text { предложению (медиана) }\end{array}$ & z-критерий & & \\
\hline 23 & $11,29 \%$ & $-2,03 \%$ & 1,92 & & \\
\hline \multicolumn{4}{|c|}{$(8)$} & $(4,31 \%)$ & $(-2,17 \%)$ \\
\hline $\begin{array}{c}\text { Панельный анализ 6: } \\
\text { Сравнение доходности в } \\
\text { зависимости от продажи } \\
\text { фондом акций компании }\end{array}$ & $\begin{array}{l}\text { Средняя доходность } \\
\text { IPO, где доля фонда } \\
\text { уменьшилась (ме- } \\
\text { диана) }\end{array}$ & $\begin{array}{c}\text { Средняя доходность IPO, где } \\
\text { доля фонда не изменилась } \\
\text { или увеличилась (медиана) }\end{array}$ & Z-критерий & & \\
\hline $\begin{array}{c}\text { Доля фонда уменьшилась } \\
\text { во время IPO (увели- } \\
\text { чилась или осталось } \\
\text { неизменной), количество } \\
\text { компаний } \\
\end{array}$ & $\begin{array}{c}\text { Средняя доход- } \\
\text { ность IPO, где доля } \\
\text { фонда уменьшилась } \\
\text { (медиана) }\end{array}$ & $\begin{array}{c}\text { Средняя доходность IPO, где } \\
\text { доля фонда не изменилась } \\
\text { или увеличилась (медиана) }\end{array}$ & Z-критерий & & \\
\hline 23 & $9,12 \%$ & $5,20 \%$ & 0,63 & & \\
\hline (8) & $(2,30 \%)$ & $(2,05 \%)$ & & & \\
\hline
\end{tabular}

Основная цель фонда прямых инвестиций в процессе публичного предложения акций выход из осуществленных ранее инвестиций в частную компанию. В этой связи интересно посмотреть, влияет ли размер проданной доли фонда во время публичного предложения значимой переменной на доходность акции компании. В качестве переменной был взят показатель изменения владения компании фондом. Выборка разделилась на две группы: компании, в которых фонд уменьшил свое участие; компании, в которых фонд не изменил или увеличил свое участие. В первую группу попали 23 компании со средней доходностью $9,12 \%$, во вторую - восемь компаний со средней доходностью 5,2\%. Несмотря на то что при успешном предложении акций фонд может выйти как можно скорее из произведенных ранее инвестиций, статистически это оказалось не значимым и не влияющим на среднюю первоначальную доходность, превышающую рыночную доходность.

При помощи панельного анализа удалось выявить, что только спрос на акции оказался значимой переменной при сравнении подгрупп в выборке по разным показателям. Компании с высоким спросом на акции показали среднюю первоначальную доходность выше компаний, у которых спрос на акции был равен или ниже предложения. Данный вывод является закономерным и укладывается в рамки экономической теории.

Результаты множественной регрессии по выявлению факторов, влияющих на первоначальную доходность, превышающий рыночную доходность, приведены в таблице 4.

\section{Результаты регрессии}

\begin{tabular}{|c|c|c|}
\hline & Коэфф. & t cmam. \\
\hline Intercept & 0,00 & 0,00 \\
\hline EXANTE & 0,63 & $3,50^{*}$ \\
\hline OVRS & 0,01 & $1,75^{* *}$ \\
\hline PSO & 0,08 & 0,51 \\
\hline MV & $-2,48$ & $-0,36$ \\
\hline IND & 0,11 & $1,83^{* *}$ \\
\hline TIM & $-0,01$ & $-0,08$ \\
\hline R кв. & 0,55 & \\
\hline Ск. R кв. & 0,43 & \\
\hline F cmam. & 4,8 & \\
\hline
\end{tabular}


*-1\%-ный уровень значимости

** - 10\%-ный уровень значимости

Уравнение в целом является значимым, как указывает $\mathrm{F}$ - статистика, которая превышает критическое значение. R-квадрат имеет значение 0,55 , это указывает на то, что более половины случаев может быть объяснено данным уравнением. Неопределенность еx-ante является значимой независимой переменной при уровне значимости в один процент, что соответствует теории инвестиционного портфеля. При росте волатильности в один процентный пункт первоначальная доходность вырастет на 0,63 процентных пункта при прочих равных.

Отрасль является значимой независимой переменной при уровне значимости $10 \%$. Исходя из уравнения в среднем при прочих равных условиях первоначальная доходность отраслей информационные технологии и финансы будут выше первоначальной доходности остальных отраслей на 0.11 процентных пункта. Значимость переменной отрасли говорит о том, что акции компаний, работающих в отраслях «информационные технологии» и «финансы», оценены во время периода подписки менее корректно, чем акции компаний из других отраслей. Также возможен особый интерес инвесторов к компаниям, работающих в высокотехнологических отраслях, что влияет на повышенный спрос на акции данных компаний после первичного публичного предложения.

Превышение лимита подписки также является значимой независимой переменной при уровне значимости 10\%. Превышение лимита подписки на один процентный пункт приведет к росту первоначальной доходности публичного предложения акций на 0,01 процентного пункта и прочих равных условиях. Превышение лимита подписки говорит о повышенном спросе на акции во время периода подписки, что может также влиять на спрос на акции после осуществления первичного публичного предложения.

Количество предложенных акций не является значимой независимой переменной для определения первоначальной доходности акций компаний, осуществивших первичное публичное предложение при помощи фондов прямых инвестиций. Это можно объяснить тем, что в случае фондов количество предложенных акций не является сигналом инвесторам. Главным образом фонды заинтересованы в продаже акций по максимально возможной цене, а не в позитивном настрое инвесторов на будущее. Стадия развития рынка и волатильность рынка, судя по результатам множественной регрессии, также не являются значимыми независимыми переменными. Возможно, это связано с тем, что в основном фонды прямых инвестиций старались осуществлять выход из портфельных компаний в подходящие для этого моменты. В 26 случаях предложение было осуществлено во время роста рынка, пять предложений было осуществлено в самом начале спада экономической активности. Волатильность рынка до первичного предложения акций не являлась значимой независимой переменной для определения первоначальной доходности, скорее всего, по причине того, что фонды выбирали подходящее время для выхода из своих портфельных инвестиций. Волатильность рынка в то время когда фонды прямых инвестиций осуществляли публичное предложение акций, не превышала $2 \%$, а в большинстве случаев она не превысила $1 \%$.

\section{Долгосрочная доходность, превышиющая рынок}

Анализ долгосрочной доходности акций компаний, которые были выведены на фондовую биржу фондами прямых инвестиций, позволит понять, насколько компании могут успешно функционировать в долгосрочной перспективе. Под долгосрочной доходностью понимается доходность, превышающая рыночную доходность в течение 252 дней после первичного предложения акций.

На основе анализа данных и статистических тестов удалось выяснить, что доходность акций в течение года после первичного предложения оказалась ниже доходности рынка. Средняя долгосрочная доходность акций компаний в течение 252 дней после первичного предложения была отрицательной - -3,41\%. Результат t-теста показал незначимость отличия средней долгосрочной доходности, превышающей рыночную доходность, от нуля. В связи с тем что данные в выборке не имеют нормального распределения, использован непараметрический 
тест, который подтвердил выводы t-теста. Таким образом, можно отклонить тезис о том, что долгосрочная доходность акций компаний, которые попали на фондовую биржу при помощи фондов прямых инвестиций, превышает доходность рынка.

Помимо сравнения долгосрочной доходности акций компаний с рыночной доходностью был проведен анализ зависимости доходности акций от разных параметров. Как и в случае с первоначальной доходностью, выборка была разделена на две подгруппы исходя из следующих параметров: состояние развития рынка, отрасль, неопределенность ex-ante, превышение лимита подписки, доля владения фондом компании.

Как показал U-критерий Манна-Уитни, долгосрочная доходность, превышающая рыночную доходность, не зависит от стадии развития экономики. Непараметрический тест показал то, что доходность компаний, действующих при подъеме экономики, статистически не отличается от доходности компаний, действующих во время рецессии. Прибыльные, так же как и убыточные, первичные предложения акций могут быть как во время подъема экономики, так и во время спада.

Отрасль также не является значимой переменной, влияющей на долгосрочную доходность, как показал статистический тест. Средняя долгосрочная доходность акций компаний из отраслей «финансы» и «информационные технологии» была выше рыночной доходности на 4.53\%. Средняя долгосрочная доходность акций компаний из других отраслей была ниже рыночной доходности на $2.93 \%$. Хотя разница между показателями доходности заметна, статистически различие доходностей незначимо.

Таблица 5

Долгосрочная доходность, превышающая рынок

\begin{tabular}{|c|c|c|c|c|c|}
\hline \multicolumn{4}{|c|}{ Панельный анализ 1: Общая выборка (30 компаний) } & & \\
\hline Фирмы с доходом > 0 & $\begin{array}{l}\text { Фирмы с доходом } \\
\leq 0\end{array}$ & Среднее (медиана) & t-критерий & & \\
\hline (z-критерий) & 16 & $3.41 \%$ & -0.50 & & \\
\hline 14 & 16 & $3,41 \%$ & $-0,50$ & & \\
\hline & & & $(-2 \%)$ & $(0,43)$ & \\
\hline $\begin{array}{c}\text { Панельный анализ 2: } \\
\text { Сравнение доходности } \\
\text { в зависимости от года } \\
\text { IPO }\end{array}$ & & $\begin{array}{c}\text { Средняя доходность во } \\
\text { время медвежьего рынка } \\
\text { (медиана) }\end{array}$ & $\begin{array}{c}\text { U - критерий } \\
\text { Манна-Уитни }\end{array}$ & & \\
\hline $\begin{array}{c}\text { Количество IPО во } \\
\text { время «бычьего» рын- } \\
\text { ка («медвежьего») }\end{array}$ & $\begin{array}{c}\text { Средняя доход- } \\
\text { ность во время } \\
\text { «бычьего» рынка } \\
\text { (медиана) }\end{array}$ & $\begin{array}{c}\text { Средняя доходность во } \\
\text { время «медвежьего» рын- } \\
\text { ка (медиана) }\end{array}$ & $\begin{array}{c}\text { U-критерий Ман- } \\
\text { на-Уитни }\end{array}$ & & \\
\hline 20 & $4,38 \%$ & $18,98 \%$ & 63 & & \\
\hline \multicolumn{3}{|c|}{$(10)$} & $(3,95 \%)$ & $(-35,23 \%)$ & \\
\hline $\begin{array}{c}\text { Панельный анализ 3: } \\
\text { Сравнение доходности } \\
\text { в зависимости от } \\
\text { отрасли }\end{array}$ & & $\begin{array}{c}\text { Средняя доходность в } \\
\text { отраслях отличных от } \\
\text { финансов и ИТ (медиана) }\end{array}$ & z-критерий & & \\
\hline $\begin{array}{c}\text { Количество IPО в от- } \\
\text { раслях финансы и ИТ } \\
\text { (остальные отрасли) }\end{array}$ & $\begin{array}{c}\text { Средняя доход- } \\
\text { ность в отраслях } \\
\text { финансы и ИТ } \\
\text { (медиана) }\end{array}$ & $\begin{array}{c}\text { Средняя доходность в } \\
\text { отраслях отличных от фи- } \\
\text { нансов и ИТ (медиана) }\end{array}$ & z-критерий & & \\
\hline 9 & $4,53 \%$ & $-2,93 \%$ & 0,54 & & \\
\hline \multicolumn{4}{|c|}{$(21)$} & $(-4,29 \%)$ & $(-0,02 \%)$ \\
\hline $\begin{array}{c}\text { Панельный анализ 4: } \\
\text { Сравнение доходности } \\
\text { в зависимости от } \\
\text { неопределенности } \\
\text { ex-ante }\end{array}$ & $\begin{array}{c}\text { Средняя } \\
\text { доходность IPO с } \\
\text { волатильностью } \\
\text { Паркинсона } \geq 0.1 \\
\text { (медиана) }\end{array}$ & $\begin{array}{c}\text { Средняя доходность } \\
\text { IPO с волатильностью } \\
\text { Паркинсона }<0.1 \\
\text { (медиана) }\end{array}$ & $\begin{array}{c}\text { U - критерий } \\
\text { Манна-Уитни }\end{array}$ & & \\
\hline
\end{tabular}




\begin{tabular}{|c|c|c|c|c|c|}
\hline $\begin{array}{c}\text { Количество IPО с во- } \\
\text { латильностью Паркин- } \\
\text { сона } \geq 0.1(<0.1)\end{array}$ & $\begin{array}{c}\text { Средняя до- } \\
\text { ходность IPО с } \\
\text { волатильностью } \\
\text { Паркинсона } \geq 0.1 \\
\text { (медиана) }\end{array}$ & $\begin{array}{c}\text { Средняя доходность IPO с } \\
\text { волатильностью Паркин- } \\
\text { сона }<0,1 \text { (медиана) }\end{array}$ & $\begin{array}{c}\text { U - критерий } \\
\text { Манна-Уитни }\end{array}$ & & \\
\hline 14 & $-9,64 \%$ & $2,05 \%$ & 93 & & \\
\hline \multicolumn{4}{|c|}{ (16) } & $(-14,72 \%)$ & $(0,64 \%)$ \\
\hline $\begin{array}{c}\text { Панельный анализ 5: } \\
\text { Сравнение доходности } \\
\text { в зависимости от } \\
\text { превышения лимита } \\
\text { подписки } \\
\end{array}$ & $\begin{array}{c}\text { Средняя } \\
\text { доходность IPO со } \\
\text { спросом больше } \\
\text { предложения } \\
\text { (медиана) } \\
\end{array}$ & $\begin{array}{c}\text { Средняя доходность } \\
\text { IPО со спросом меньше } \\
\text { или равно предложению } \\
\text { (медиана) }\end{array}$ & Z-критерий & & \\
\hline $\begin{array}{c}\text { Спрос на акции во } \\
\text { время IPО больше } \\
\text { предложения (меньше } \\
\text { или равно), количе- } \\
\text { ство компаний }\end{array}$ & $\begin{array}{l}\text { Средняя доход- } \\
\text { ность IРО со } \\
\text { спросом больше } \\
\text { предложения } \\
\text { (медиана) }\end{array}$ & $\begin{array}{c}\text { Средняя доходность } \\
\text { IPO со спросом меньше } \\
\text { или равно предложению } \\
\text { (медиана) }\end{array}$ & Z-критерий & & \\
\hline 23 & $5,76 \%$ & $-33,52 \%$ & 7,89 & & \\
\hline \multicolumn{4}{|c|}{ (7) } & $(5,57 \%)$ & $(-41,03 \%)$ \\
\hline $\begin{array}{c}\text { Панельный анализ 6: } \\
\text { Сравнение доходности } \\
\text { в зависимости от } \\
\text { продажи фондом } \\
\text { акций компании }\end{array}$ & $\begin{array}{c}\text { Средняя } \\
\text { доходность IPO, } \\
\text { где доля фонда } \\
\text { уменьшилась } \\
\text { (медиана) }\end{array}$ & $\begin{array}{c}\text { Средняя доходность IPO, } \\
\text { где доля фонда не из- } \\
\text { менилась или увеличилась } \\
\text { (медиана) }\end{array}$ & $\begin{array}{c}\text { U - критерий } \\
\text { Манна-Уитни }\end{array}$ & & \\
\hline $\begin{array}{c}\text { Доля фонда уменьши- } \\
\text { лась на } 30 \% \text { (увели- } \\
\text { чилась, уменьшилась } \\
\text { менее } 30 \% \text {,осталась } \\
\text { неизменной), количе- } \\
\text { ство компаний }\end{array}$ & $\begin{array}{c}\text { Средняя до- } \\
\text { ходность IPO, } \\
\text { где доля фонда } \\
\text { уменьшилась } \\
\text { (медиана) }\end{array}$ & $\begin{array}{c}\text { Средняя доходность IPO, } \\
\text { где доля фонда не из- } \\
\text { менилась или увеличилась } \\
\text { (медиана) }\end{array}$ & $\begin{array}{c}\text { U-критерий Ман- } \\
\text { на-Уитни }\end{array}$ & & \\
\hline 17 & $9,08 \%$ & $4 \%$ & 122,5 & & \\
\hline$(13)$ & $(-6,08 \%)$ & $(16,65 \%)$ & & & \\
\hline
\end{tabular}

Доходность акций с волатильностью Паркинсона превышающей $10 \%$ была ниже рыночной доходности на 9.64\%, когда доходность акций с волатильностью менее $10 \%$ была выше рынка на 2.05\%. U - критерий Манна-Уитни для этих подгрупп превышает критическое значение, что говорит о незначимом отличии средних значений двух подгрупп.

Фонды прямых инвестиций полностью продали свои доли в семи компаниях при первичном предложении акций. В течение года после публичного предложений акций фонды полностью продали свои доли еще в шести компаниях, за это же время фонды уменьшили свои доли без полной продажи в десяти компаниях. Для оценки значимости уменьшения долевого владения фондами портфельных компаний мы разделили выборку на две группы. К первой группе относятся компании, в которых более $30 \%$ акций было продано фондами с момента первоначального предложения и до конца года после публичного предложения акций. Ко второй группе относятся компании, в которых менее 30\% акций было продано фондами. Как показало исследование, долгосрочная доходность акций первой группы была на 9,08\% выше рыночной доходности, а долгосрочная доходность акций компаний второй группы была на 4\% выше рынка. Статистически данное различие не является значимым, т.к. U-критерий Манна-Уитни превысил в результате статистического теста критическое значение.

Единственно значимым параметром, как и при анализе первоначальной доходности, оказался спрос на акции. Как и при первоначальной доходности, чем выше был первоначальный спрос на акции, тем выше доходность. Компании, на чьи акции спрос превышал предложение при первичном предложении, показали долгосрочную доходность, превышающую рынок на 5,76\%. При этом компании, чьи акции не пользовались спросом изначально, показали падение в 33,52\% ниже рынка. Отличие в средних показателях долгосрочной доходности является статистически значимым при однопроцентным уровне значимости. 


\section{Выводы}

В статье анализируются краткосрочная и долгосрочная доходности, превышающие рыночную доходность акций польских компаний, которые были выведены на Варшавскую фондовую биржу при помощи фондов прямых инвестиций. Всего в выборку вошли данные 31 компании, чьи акции были размещены на фондовой бирже с 2004 по 2014 г., с общим объемом предложения, превышающим 1 млрд долл. США.

Статистический анализ показал, что первоначальная доходность акций компаний превышает рыночную доходность. В среднем акции компаний показали доходность, которая была на 7.85\% выше рыночной доходности. Во-первых, можно сделать вывод, что фонды прямых инвестиций посредством публичного предложения акций портфельных компаний генерируют прибыль, превышающую рыночную доходность. Во-вторых, оценка портфельных компаний фондов прямых инвестиций во время периода подписки на акции ближе к рыночной цене, чем в среднем по рынку. Таким образом, фонды прямых инвестиций могут генерировать прибыль, превышающую доходность рынка, через выход из первоначальных инвестиций в портфельные компании путем публичного предложения акций. Также у фондов прямых инвестиций нет стимулов к занижению стоимости акций компаний и оценка акций компаний получается ближе к справедливой стоимости, чем в среднем на рынке.

Основными факторами, определяющими первоначальную доходность, являются неопределенность ex-ante, превышение лимита подписки и отрасль, в которой работает портфельная компания. Данный вывод следует из анализа множественной регрессии и совпадает с экономической теорией, лежащей в основе выбора данных независимых переменных. Неопределенность, связанная с будущими результатами компании, должна стимулировать компании к занижению цены на акции, чтобы компенсировать инвесторам потенциальные риски. Превышение лимита подписки говорит о спросе инвесторов на акции компании. Изначальный спрос на акции существует и после первичного предложения в связи с тем, что не все инвесторы в полном объеме удовлетворили свою потребность в покупке акций компании во время периода подписки. Финансы и информационные технологии привлекают к себе больше внимание инвесторов, чем остальные отрасли. Этим можно объяснить повышенный спрос на акции данных компаний во время первичного предложения акций. Количество предложенных акций, волатильность рынка и стадия его развития оказались незначимыми независимыми переменными для определения первоначальной доходности акций компаний.

Долгосрочная доходностьакцийкомпаний, осуществившихпервичноепубличноепредложение при помощи фондов прямых инвестиций, оказалась ниже рыночной доходности. Разница между долгосрочной доходностью акций компаний и рыночной доходностью статистически не отличается от нуля. Данный вывод соответствует ряду исследований динамики цен акций после осуществления первичного публичного предложения. Таким образом, сложно выявить особую роль фондов в увеличении прибыльности и производительности, улучшении операционной деятельности портфельных компаний в долгосрочной перспективе.

\section{Список литературы}

1. Agarwal, S., Liu, Ch., and Rhee, S.G. (2008), "Investor demand for IPOs and aftermarket Performance: evidence from the Hong Kong Stock Market", Journal of International Financial Markets, Institutions \& Money, No. 18, pp.176-190.

2. Aggraval, R., and Rivoli, P. (1990), "Fads in the initial public offering market?", Financial Management, No. 19, pp. 45-57.

3. Allen, F., and Faulhaber, G.R. (1989), "Signaling by underpricing in the IPO market", Journal of Financial Economics, No. 23, pp.303-323.

4. Al-Hassan, A., Delgado, F., and Omran, M. (2007), "IPO behaviour in GCC Countries: coody-two shoes or bad-to-the-bone?", IMF Working Paper, No. 149. Available at: www. 
imf.org/external/pubs/cat/longres.aspx?sk=21032.0 (Accessed 1 October 2015).

5. Cohn, J.B., Mills, L.F., and Towery, E.M. (2013), "The evolution of capital structure and operating performance after leveraged buyout: evidence from U.S. corporate tax return", McCobbs Research Paper Series, No. Acc-02-11. Available at: http://papers.ssrn.com/sol3/ papers.cfm?abstract_id=1764406 (Accessed 1 October 2015).

6. Derrien, F., and Womack, K. (2003), "Auctions vs. bookbuilding and the control of underpricing in hot IPO markets", Review of Financial Studies, No. 16, pp. 31-61.

7. Guo, S., Hotchkiss, E.S. and Song, W. (2008), "Do buyouts (still) create value?", NBER Working Paper, No. 14187. Available at: www.nber.org/papers/w14187 (Accessed 1 October 2015).

8. How, J., Izan, H., and Monroe, G. (2009), "Differential information and the underpricing of initial public offerings: Australian evidence", Accounting and Finance, Vol. 35, No. 1, pp. 87-105.

9. Ibbotson, R.G. (1975), "Price performance of common stock new issues", Journal of Financial Economics, Vol.2, No. 3, pp. 235-272.

10. Jensen, M. (1989), "The eclipse of the public corporation", Harvard Business Review, Vol. 67, pp. 61-74.

11. Klonowski, D. (2011), "Private equity in Poland after two decades of development: evolution, industry drivers, and returns", An International Journal of Entrepreneurial Finance, Vol.13, pp. 295-311.

12. Knopf, J.D., and Teall, J.L. (1999), "The IPO effect and measurement of risk", Journal of financial and strategic decisions, Vol. 12, No. 2.

13. Lichtenberg, F.R., and Siegel, D. (1989), "The effects of leveraged buyouts on productivity and related aspects of firm behaviour", NBER Working Paper, No. 3022. Available at: www. nber.org/papers/w3022 (Accessed 1 October 2015).

14. Menyah, K., Paudyal, K., and Inyangete, C. (1995), "Subscriber return, underpricing, and longterm performance of UK privatization initial public offers", Journal of Economics and Business, Vol. 47, No. 5, pp. 473-495.

15. Michaely, R., and Shaw, W.H. (1994), "The pricing of initial public offerings: test of adverseselection and signaling theories", The Review of Financial Studies, Vol.7, No. 2.

16. National Bank of Poland (2015) Data derived from: 'Interest rates statistics 2004 - 2014'. Available at: URL: http://www.nbp.pl/homen.aspx?f=/en/statystyka/oproc/oproc.html (Accessed 1 October 2015)

17. Ritter, J.R. (1991), "The long run performance of initial public offerings", Journal of Finance, Vol. 46, No. 1, pp. 3-27.

18. Rock, K. (1986), "Why new issues are underpriced", Journal of Financial Economics, No. 15, pp. 187-212.

19. Sieradzki, R. (2013), "Doest it pay to invest in IPOs? Evidence from the Warsaw Stock Exchange", Working paper of National Bank of Poland, No. 139. Available at: www.nbp.pl/ publikacje/materialy i studia/139 en.pdf (Accessed 1 October 2015).

20. Warsaw Stock Exchange (2015), Data derived from: 'Capitalization and number of companies listed on the Warsaw Stock Exchange 1991 - 2015'. Available at: http://www.gpw.pl/ analizy i statystyki en (Accessed 1 October 2015).

21. Warsaw Stock Exchange (2015), Data derived from: 'Quotation archive of companies listed on the Warsaw Stock Exchange'. Available at: http://www.gpwinfostrefa.pl/GPWIS2/pl/ quotes/archive/1 (Accessed 1 October 2015).

22. Welch, I. (1989), "Seasoned offerings, imitation costs, and the underpricing of initial public offerings", Journal of Finance, Vol. XLV, No. 2. 
23. Wilson, N., and Wright, M. (2013), "Private equity, buy-outs and insolvency risk", Journal of Business Finance \& Accounting, Vol. 40, No. 7, pp. 949-990.

24. World Bank (2015), Data derived from: 'GDP (current US\$) 1991 - 2014'. Available at: http://data.worldbank.org/indicator/NY.GDP.MKTP.CD (Accessed 1 October 2015).

25. World Bank (2015), Data derived from: 'Market capitalization of listed companies (current US\$) 1991-2014'. Available at: http://data.worldbank.org/indicator/CM.MKT.LCAP.CD (Accessed 1 October 2015).

26. World Bank (2015), Data derived from: 'Market capitalization of listed companies (\% of GDP) 1991-2014'. Available at: http://data.worldbank.org/indicator/CM.MKT.LCAP. GD.ZS (Accessed 1 October 2015).

27. World Federation of Exchanges (2015) Data derived from: 'Market capitalization of stock exchanges 2013-2014'. Available at: http://www.world-exchanges.org/statistics/annualquery-tool (Accessed 1 October 2015). 


\title{
PRIVATE EQUITY PORTFOLIO COMPANIES PERFORMANCE: EVIDENCE FROM THE CENTRAL EUROPEAN PUBLIC COMPANIES
}

\author{
Anton Prokhorenko, \\ Postgraduate student, Faculty of Economics Lomonosov Moscow State University \\ Citibank Europe plc.
}

\begin{abstract}
The article analyses the return of Private Equity portfolio companies, which made an initial public offering in the Central Europe from 2004 to 2014. The ability of the Private Equity funds to generate the abnormal return remains under the question in the academic literature due to limited information regarding Private Equity deals which are available to researches. The analysis of Private Equity portfolio companies' performance, which made an initial public offering, will show the bigger picture and will allow to understand better the Private Equity willingness to generate return, that exceeds the market return. An aggregate data of the initial public offerings on the Warsaw Stock Exchange of thirty one companies with a total value more than one billion USD has been analysed in the article. The parametric and nonparametric tests were used to analyse the statistical significance of the differences of an initial abnormal return and an aftermarket abnormal return from zero. The MannWhitney test was used for analysing the difference in means of sub-samples, created in order to the following criteria: market sentiment, industry, ex-ante uncertainty, oversubscription, ownership. The multiple regression was used to determine the factors which have an influence on an initial abnormal return of Private Equity portfolio companies. The results of the analyses are in compliance with the similar researches: the initial return of Private Equity portfolio companies is above the market return; the aftermarket return of Private Equity portfolio companies is not statistically different from the market return. The main factors which determine an initial abnormal return are: ex-ante uncertainty, oversubscription and industry.
\end{abstract}

Key words:Private Equity funds, initial public offering, stock performance, Central Europe

JEL G12, G24

\section{References}

1. Agarwal, S., Liu, Ch. and Rhee, S.G. (2008), "Investor demand for IPOs and aftermarket Performance: evidence from the Hong Kong Stock Market”, Journal of International Financial Markets, Institutions \& Money, No. 18, pp.176-190.

2. Aggraval, R. and Rivoli, P. (1990), "Fads in the initial public offering market?", Financial Management, No. 19, pp. 45-57.

3. Allen, F. and Faulhaber, G.R. (1989), "Signaling by underpricing in the IPO market", Journal of Financial Economics, No. 23, pp.303 - 323.

4. Al-Hassan, A., Delgado, F. and Omran, M. (2007), "IPO behaviour in GCC Countries: coody-two shoes or bad-to-the-bone?", IMF Working Paper, No. 149. Available at: www. imf.org/external/pubs/cat/longres.aspx?sk=21032.0 (Accessed 1 October 2015).

5. Cohn, J.B., Mills, L.F. and Towery, E.M. (2013), "The evolution of capital structure and operating performance after leveraged buyout: evidence from U.S. corporate tax return", McCobbs Research Paper Series, No. Acc-02-11. Available at: http://papers.ssrn.com/sol3/ papers.cfm?abstract id=1764406 (Accessed 1 October 2015).

6. Derrien, F. and Womack, K. (2003), "Auctions vs. bookbuilding and the control of underpricing in hot IPO markets", Review of Financial Studies, No. 16, pp. 31-61.

7. Guo, S., Hotchkiss, E.S. and Song, W. (2008), "Do buyouts (still) create value?", NBER Working Paper, No. 14187. Available at: www.nber.org/papers/w14187 (Accessed 1 October 2015).

8. How, J., Izan, H. and Monroe, G. (2009), "Differential information and the underpricing of initial public offerings: Australian evidence", Accounting and Finance, Vol. 35, No. 1, pp. $87-105$. 
9. Ibbotson, R.G. (1975), "Price performance of common stock new issues", Journal of Financial Economics, Vol.2, No. 3, pp. 235-272.

10. Jensen, M. (1989), "The eclipse of the public corporation", Harvard Business Review, Vol. 67, pp. 61-74.

11. Klonowski, D. (2011), "Private equity in Poland after two decades of development: evolution, industry drivers, and returns", An International Journal of Entrepreneurial Finance, Vol.13, pp. 295-311.

12. Knopf, J.D. and Teall, J.L. (1999), “The IPO effect and measurement of risk", Journal of financial and strategic decisions, Vol. 12, No. 2.

13. Lichtenberg, F.R. and Siegel, D. (1989), "The effects of leveraged buyouts on productivity and related aspects of firm behaviour", NBER Working Paper, No. 3022. Available at: www. nber.org/papers/w3022 (Accessed 1 October 2015).

14. Menyah, K., Paudyal, K. and Inyangete, C. (1995), "Subscriber return, underpricing, and longterm performance of UK privatization initial public offers", Journal of Economics and Business, Vol. 47, No. 5, pp. 473-495.

15. Michaely, R. and Shaw, W.H. (1994), "The pricing of initial public offerings: test of adverseselection and signaling theories", The Review of Financial Studies, Vol.7, No. 2.

16. National Bank of Poland (2015) Data derived from: 'Interest rates statistics 2004 - 2014'. Available at: URL: http://www.nbp.pl/homen.aspx?f=/en/statystyka/oproc/oproc.html (Accessed 1 October 2015)

17. Ritter, J.R. (1991), "The long run performance of initial public offerings", Journal of Finance, Vol. 46, No. 1, pp. 3-27.

18. Rock, K. (1986), "Why new issues are underpriced", Journal of Financial Economics, No. 15, pp. 187-212.

19. Sieradzki, R. (2013), "Doest it pay to invest in IPOs? Evidence from the Warsaw Stock Exchange", Working paper of National Bank of Poland, No. 139. Available at: www.nbp.pl/ publikacje/materialy_i studia/139 en.pdf (Accessed 1 October 2015).

20. Warsaw Stock Exchange (2015) Data derived from: 'Capitalization and number of companies listed on the Warsaw Stock Exchange 1991 - 2015'. Available at: http://www.gpw.pl/ analizy_i_statystyki_en (Accessed 1 October 2015).

21. Warsaw Stock Exchange (2015) Data derived from: 'Quotation archive of companies listed on the Warsaw Stock Exchange'. Available at: http://www.gpwinfostrefa.pl/GPWIS2/pl/ quotes/archive/1 (Accessed 1 October 2015).

22. Welch, I. (1989), "Seasoned offerings, imitation costs, and the underpricing of initial public offerings", Journal of Finance, Vol. XLV, No. 2.

23. Wilson, N. and Wright, M. (2013), "Private equity, buy-outs and insolvency risk", Journal of Business Finance \& Accounting, Vol. 40, No. 7, pp. 949-990.

24. World Bank (2015) Data derived from: 'GDP (current US\$) 1991 - 2014'. Available at: http://data.worldbank.org/indicator/NY.GDP.MKTP.CD (Accessed 1 October 2015).

25. World Bank (2015) Data derived from: 'Market capitalization of listed companies (current US\$) 1991 - 2014'. Available at: http://data.worldbank.org/indicator/CM.MKT.LCAP.CD (Accessed 1 October 2015).

26. World Bank (2015) Data derived from: 'Market capitalization of listed companies (\% of GDP) 1991 - 2014'. Available at: http://data.worldbank.org/indicator/CM.MKT.LCAP. GD.ZS (Accessed 1 October 2015).

27. World Federation of Exchanges (2015) Data derived from: 'Market capitalization of stock exchanges 2013 - 2014'. Available at: http://www.world-exchanges.org/statistics/annualquery-tool (Accessed 1 October 2015). 